\title{
Effect of Biopesticides on Foliar Diseases and Japanese Beetle (Popillia japonica) Adults in Roses (Rosa spp.), Oakleaf Hydrangea (Hydrangea quercifolia), and Crapemyrtle (Lagerstroemia indica)
}

\author{
M.T. Mmbaga and J.B. Oliver
}

\begin{abstract}
This study evaluated efficacy of biopesticides for reducing foliar diseases and feeding damage from Japanese beetle adults on hybrid T rose (Rosa spp.), oakleaf hydrangea (Hydrangea quercifolia), and crapemyrtle (Lagerstroemia indica). The materials tested included household soaps with Triclosan active ingredient (Equate ${ }^{\circledR}$ and Ajax ${ }^{\circledR}$ ), kaolin clay (Surround ${ }^{\circledR}$ ), neem seed oil extract (Triact $70^{\circledR}$ and Neem Gold ${ }^{\circledR}$ ), potassium salt of fatty acids (M-Pede ${ }^{\circledR}$ ), horticultural oil (UltraFine ${ }^{\circledR}$ Sunspray oil), and bicarbonate salt (Armicarb $\left.{ }^{\circledR}\right)$ applied to plants grown under greenhouse, shadehouse, and field conditions. Two fungicides, trifloxystrobin (Strobilurin) and triadimefon (Triazole), and the insecticide carbaryl were included for comparison. All materials tested were effective in controlling black spot (Marssonina rosae, anamorph Diplocarpon rosae) and powdery mildew (Sphaerotheca pannosa) of roses. Kaolin was effective in reducing disease severity of bacterial leaf spot (Xanthomonas campestris) on oakleaf hydrangea and powdery mildew of crapemyrtle. Based on data from repeated trials, the biopesticides were as effective as conventional fungicides in suppressing foliar diseases. Kaolin clay was as effective as carbaryl in controlling Japanese beetle adult feeding damage on oakleaf hydrangea, roses, and crapemyrtle, but other products were not effective. Results from this study indicate kaolin clay may be an alternative product to conventional pesticides in foliar diseases and insect pest management for roses, oakleaf hydrangea, and crapemyrtle.
\end{abstract}

Key Words. Black spot; fungicides; insecticides; Japanese beetle; pest management; powdery mildew; Xanthomonas leaf spot.

Nursery production of ornamental plants relies heavily on conventional pesticides to manage disease and insect pests (Sinclair et al. 1993; Windham 1994; Hagan and Mullen 1995; Garber and Hudson 1996; Daughtrey and Hagan 2001; Jones and Benson 2004). Powdery mildew fungi (Oidium spp. and Oidiopsis spp.) are widespread and problematic in the production of many ornamental plants, including Cornus florida, Quercus spp., Lagerstroemia spp., Photinia serrulata, Lonicera spp., Malus spp., Platanus spp., Syringa spp., Magnolia liliflora, Euonymus spp., Hydrangea spp., Rosa spp., Spirea spp., Leucothoe spp., and Viburnum spp. (Sinclair et al. 1993). In addition to reducing the aesthetic value of landscape plants, powdery mildew reduces leaf expansion, photosynthetic capability, and overall plant growth (Ellis et al. 1981).

Powdery mildew caused by Sphaerotheca pannosa (Wallr. Ex Fr.) (anamorph Oidium spp.) is a serious disease in greenhouses and field grown roses (Horst 1995). Roses are also affected by black spot [Marssonina rosae (Lib.) Lind, ana- morph Diplocarpon rosae Wolf]. Black spot (Figure 1) is a devastating and widespread problem that often occurs in epidemic proportions in landscape roses, but it is less of a problem in greenhouses as a result of the use of drip irrigation and relative humidity control (Horst 1995). Black spot overwinters on infected buds or leaf debris, and once established on a susceptible host, it is a persistent problem causing severe defoliation (Horst 1995). The optimum temperature for black spot is $21^{\circ} \mathrm{C}\left(69.8^{\circ} \mathrm{F}\right)$ to a maximum of $33^{\circ} \mathrm{C}\left(91.4^{\circ} \mathrm{F}\right)$ (Horst 1995; Philley et al. 2001). Free moisture (i.e., $100 \%$ relative humidity) for at least $7 \mathrm{hr}$ is required for spore germination and infection establishment. No infection occurs at relative humidity below 90\%. Thus, good air circulation around plants reduces disease severity.

Oakleaf hydrangea (Hydrangea quercifolia Bartr.) and crapemyrtle (Lagerstroemia spp.) generally have few disease problems. However, when grown under warm, humid to moderately wet conditions, oak leaf hydrangea are susceptible to a bacterial leaf spot (Xanthomonas campestris L.) 

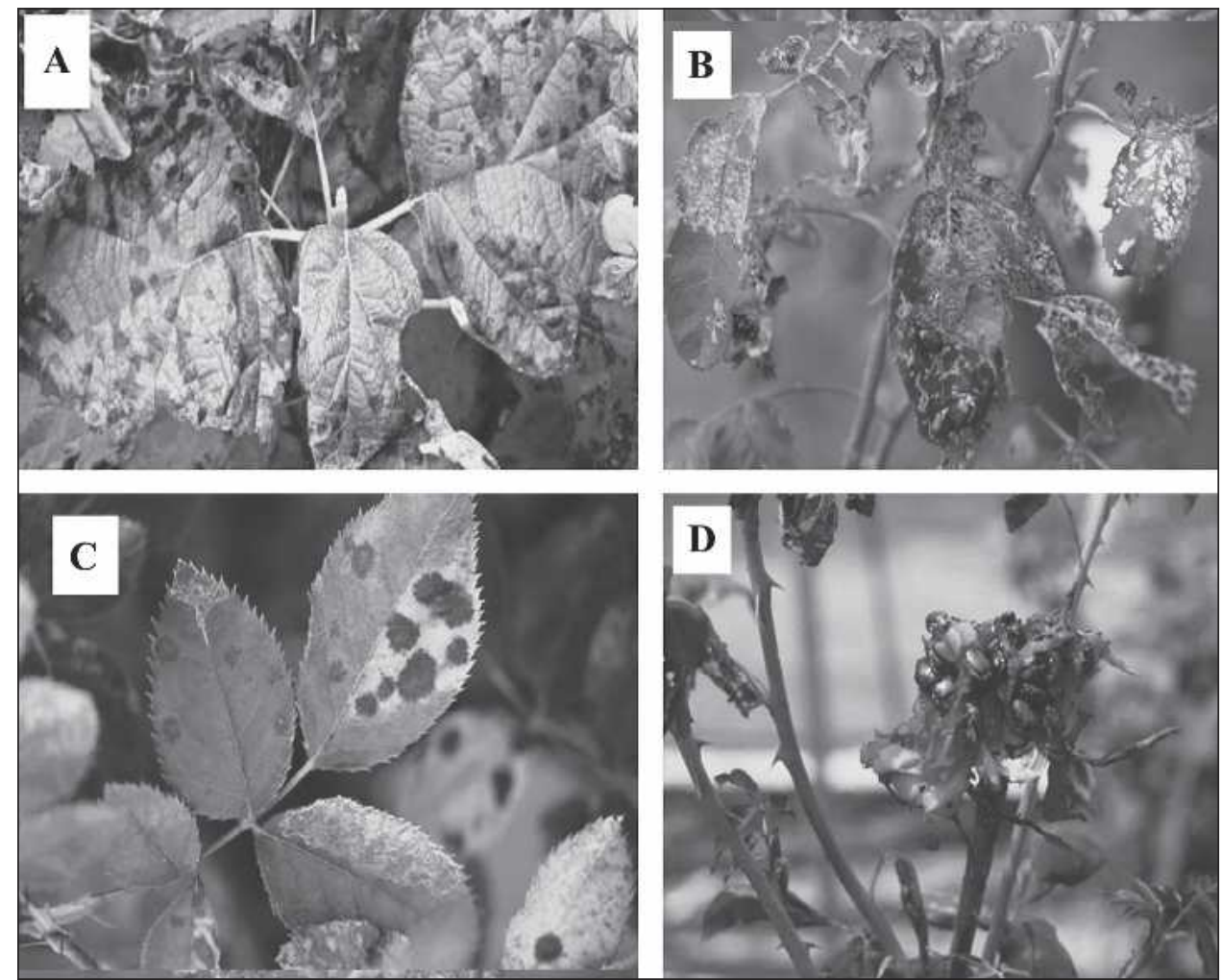

Figure 1. Disease symptoms of (A) bacteria leaf spot (Xanthomonas campestris L.) of oakleaf hydrangea (Hydrangea quercifolia Bartr.), (B) black spot (Marssonina rosae, anamorph Diplocarpon rosae) of roses (Rosa spp.), (C) adult Japanese beetle (Popillia japonica Newman) feeding damage on leaves, and (D) on flower petals of rose (Rosa spp.).

(Figure 1) and crapemyrtle is susceptible to powdery mildew [Erysiphe (sect Uncinulla) australiana (McAlpine)] (Sinclair et al. 1993; Jones and Benson 2004; Shi and Mmbaga 2006). Roses, oakleaf hydrangea, and crapemyrtle are also highly susceptible to Japanese beetle (Popillia japonica Newman) and other insects that feed on foliage and flower petals. Insect pest control in nursery and landscape settings often involves routine applications of insecticides (Bradley 1999; Garber and Hudson 1996). Integrated pest management emphasizes a reduction in the use of synthetic pesticides and it was our goal to explore environmentally acceptable alternatives.

In recent years, new pesticides have been developed that are more environmentally friendly and pest-specific with reduced mammalian toxicities (Bradley 1999). In addition, "biopesticides" developed from synthetic or natural compounds such as plants, microorganisms, and certain minerals have been shown to be effective in controlling many pest and foliar diseases (Locke 1992, 1993; Isman 1994; Stimmel 1996; Landolt et al. 1999; Bélanger and Labbe 2002; Scott et al. 2004; U.S. EPA 2005a, 2005b). Biopesticides are generally lower in toxicity, less harmful to nontarget organisms, and decompose rapidly as compared with conventional pesticides U.S. EPA 2005a).
Potassium bicarbonate and several household soaps containing 0.10 to $0.2 \%$ triclosan (Equate ${ }^{\circledR}$ liquid hand soap [Wal-Mart Stores, Inc., Bentonville, AR], Ajax ${ }^{\circledR}$ liquid dish soap [Colgate-Palmolive Company, New York, NY] and Palmolive $^{\circledR}$ liquid dish soap [Colgate-Palmolive Company, New York, NY]) were found to be effective in controlling powdery mildew [Erysiphe (Sect. Microsphaera) pulchra Cook \& Peck (Braun \& Takamatsu)] of dogwood (Cornus spp.) (Mmbaga and Sheng 2002; Mmbaga and Sauvé 2004). Applications of either potassium bicarbonate or soaps at 7-day intervals or in fungicide rotations at 14-day intervals were as effective as conventional fungicides propiconizole, thiophanate methyl, and copper sulfate pentahydrate. These fungicides are primarily used in ornamental plant powdery mildew control (Mmbaga and Sauvé 2004). However, sodium bicarbonate was not effective in Erysiphe (Sect Microsphaera) syringae of lilac (Syringae spp.) in field trials (Clement et al. 1994). The household soap Palmolive ${ }^{\circledR}$ is reported to be effective in controlling cherry, grape, and apple powdery mildew fungi (Sholberg and Boulé 2006). Thus, biopesticides have the potential to reduce the amount of fungicides used to control foliar diseases (Mmbaga and Sauvé 2004; Sholberg and Boulé 2006). 
In addition to foliar diseases, Japanese beetle adults can heavily damage roses, oakleaf hydrangea, and crapemyrtle. Feeding damage by adult Japanese beetle reduces the aesthetic value of landscape plants (Figures 1). Insecticides like bifenthrin, carbaryl, cyfluthrin, deltamethrin, and lambdacyhalothrin are routinely used to protect plants from Japanese beetle feeding (TOR 2005). In addition to feeding damage, Japanese beetle is also an important regulatory pest that imposes serious shipping restrictions on balled and burlapped (B\&B) nursery stock, and insecticides are routinely used to prevent grub infestations. The purpose of this study was to evaluate selected biopesticides for controlling foliar diseases and Japanese beetle adult feeding damage on roses, oakleaf hydrangea, and crapemyrtle.

\section{MATERIALS AND METHODS}

\section{Plant Material and Experimental Design}

Plants were purchased from commercial farms: bare-root hybrid T rose ('Ain't She Sweet') from Upland, California, U.S.; and B\&B oakleaf hydrangea (native unnamed selection) and container-grown crapemyrtle ( $L$. indica) from McMinnville, Tennessee, U.S. The dormant plants were held in a cold room at $4^{\circ} \mathrm{C}\left(39.2^{\circ} \mathrm{F}\right)$ until the end of April when they were planted in field plots at Tennessee State University, Otis L. Floyd Nursery Research Center, McMinnville, Tennessee. Planting was done in six rows consisting of plots of four plants (one oakleaf hydrangea, one rose, one crapemyrtle, and one Photinia spp.) spaced $1 \mathrm{~m}(3.3 \mathrm{ft})$ apart. Plot spacing within rows was $1.54 \mathrm{~m}(5.1 \mathrm{ft})$ and row spacing was $3.0 \mathrm{~m}$ $(9.9 \mathrm{ft})$. A total of nine biopesticides, two conventional fungicides, and one insecticide were arranged in a randomized complete block design with each treatment replicated six times (Tables 1-5). Application rates used are presented in Tables 1-5. All plants were watered as needed by drip irrigation. A controlled-release fertilizer $14 \mathrm{~N}-14 \mathrm{P}-14 \mathrm{~K}$ was applied in early May at a rate of $50 \mathrm{~g}(1.8 \mathrm{oz})$ per plant.

In addition to field plots, roses were also planted in $11.4 \mathrm{~L}$ (3 gal) plastic containers using bark, peat, and sand (3:1:1) potting mix and maintained outdoors under $50 \%$ shade or in a controlled greenhouse environment at $25^{\circ} \mathrm{C} \pm 3^{\circ} \mathrm{C}\left(77^{\circ} \mathrm{F} \pm\right.$ $37.4^{\circ} \mathrm{F}$ ). All shadehouse and greenhouse plants were watered daily by drip irrigation. A controlled-release fertilizer $14 \mathrm{~N}-$ $14 \mathrm{P}-14 \mathrm{~K}$ was applied in early May at the rate of $50 \mathrm{~g}(1.8 \mathrm{oz})$ per container. The experiments were set up as a randomized complete block design with six replicates of individual plants per treatment. Treatments applied were similar to those previously described under field plots (Tables 1 and 4).

All treatments for disease control in field, shadehouse, and greenhouse trials were initiated in early May soon after the first disease symptoms were observed in a few plants. Crapemyrtle budbreak occurs later than in roses and hydrangea, and plants were not sprayed until first disease symptoms were observed. When adult Japanese beetles were detected in traps starting early June, the insecticide Sevin SL ${ }^{\circledR}$ (Bayer Environmental Sciences, Montvale, NJ) was added in a tank mix with the fungicide trifloxystrobin (Compass ${ }^{\circledR}$, Olympic Horticultural Products Company, Mainland, PA) to control insects in field and shadehouse trials. All treatments were applied at 10- to 14-day intervals and sprayed to run off using $\mathrm{CO}_{2}$ powered sprayers with a flat-fan nozzle at 12 psi pressure (R\&D Sprayers, Appaloosas, MS). Treatments were terminated in October.

\section{Disease Evaluation and Insect Feeding Damage}

Foliar diseases developed naturally without artificial inoculations. The main foliar diseases observed on roses were powdery mildew ( $S$. pannosa) that appeared soon after budbreak in late April followed by black spot (M. rosae) that started in mid-June. Bacterial leaf spot (X. campestris) on oakleaf hydrangea and powdery mildew (E. australiana) on crapemyrtle were observed soon after budbreak in mid-May. Entomosporium leafspot developed on photinia, but the evaluation was terminated as a result of death of plants after the first year. Disease severity was evaluated monthly from May to August using a $0-5$ scale in which $1=1 \%$ to $10 \%, 2=11 \%$ to $25 \%$, $3=26 \%$ to $50 \%, 4=51 \%$ to $75 \%$, and $5=75 \%$ to $100 \%$ of plant foliage displaying signs and symptoms of disease (Horsfall and Barratt 1945). All data were analyzed using Statistical Analysis Systems (SAS) general linear models procedure and analysis of variance (ANOVA) with spray treatments as the main effect (Schlotzauer and Littell 1987; SAS Institute 1990). Multiple comparisons among treatments for mean disease severity were performed using a series of $t$ tests (Gomez and Gomez 1984; SAS Institute 1990). The least significant differences (LSD) were calculated according to Fisher's protected LSD test at $P \leq 0.05$.

Japanese beetles adult feeding damage was visually evaluated from May through August. Percentage of total leaf area consumed was recorded using a $0-10$ scale in which $0=$ no damage and $10=100 \%$ feeding damage. The data on feeding damage were converted to percentages in which $1=$ $10 \%, 2=20 \%$, and so on. All data were square root transformed and analyzed by ANOVA with spray treatments as the main effect (Schlotzauer and Littell 1987; SAS Institute 1990).

\section{RESULTS}

\section{Disease and Insect Feeding Damage}

Initial signs and symptoms of $S$. pannosa in roses were observed starting late April in the field, shadehouse, and greenhouse experiments. Initial symptoms consisted of slightly raised, blister-like areas that were often red-colored on the upper leaf surface of young leaves and later formed discrete patches of white powdery mycelia and conidiospores, which 
Table 1. Powdery mildew (Sphaerotheca pannosa) disease severity in roses (Rosa spp.) treated with disease control products under different environments.

\begin{tabular}{|c|c|c|c|c|c|c|}
\hline \multirow[b]{3}{*}{ Treatment $^{\mathrm{z}}$} & \multirow{3}{*}{$\begin{array}{l}\text { Application rate } \\
\text { (product/L of } \\
\text { water) }\end{array}$} & \multicolumn{5}{|c|}{ Highest disease severity $(0-5 \text { scale })^{\mathrm{y}}$ in three environments } \\
\hline & & \multirow{2}{*}{$\frac{\text { Greenhouse }}{2002}$} & \multirow{2}{*}{$\frac{\text { Shadehouse }^{\mathrm{x}}}{2003}$} & \multicolumn{3}{|c|}{ Field } \\
\hline & & & & 2002 & 2002 & 2003 \\
\hline Equate & $18.3 \mathrm{~mL} / \mathrm{L}(1.8 \%)$ & $1.50 \mathrm{~cd}$ & $1.00 \mathrm{~d}$ & $2.00 \mathrm{def}$ & $1.50 \mathrm{~cd}$ & $2.12 \mathrm{c}$ \\
\hline UltraFine $^{\circledR}$ & $14.0 \mathrm{~mL} / \mathrm{L}(1.4 \%)$ & $1.80 \mathrm{bcd}$ & $1.50 \mathrm{bcd}$ & $1.87 \mathrm{efg}$ & $1.8 \mathrm{bc}$ & $2.37 \mathrm{bc}$ \\
\hline $\operatorname{Ajax}^{\circledR}$ & $18.3 \mathrm{~mL}(1.8 \%)$ & $1.10 \mathrm{~d}$ & $1.13 \mathrm{~d}$ & $2.00 \mathrm{def}$ & $1.10 \mathrm{~d}$ & $2.00 \mathrm{c}$ \\
\hline Surround ${ }^{\circledR}$ & $30 \mathrm{~g} / \mathrm{L}(0.25 \mathrm{lb} / \mathrm{gal})$ & $1.50 \mathrm{~cd}$ & $1.75 \mathrm{bc}$ & $1.75 \mathrm{gf}$ & $1.50 \mathrm{~cd}$ & $2.37 \mathrm{bc}$ \\
\hline Neem Gold ${ }^{\circledR}$ & $10.0 \mathrm{~mL} / \mathrm{L}(1.0 \%)$ & $2.00 \mathrm{bcd}$ & $1.25 \mathrm{~cd}$ & 1.87 efg & $2.20 \mathrm{ab}$ & $2.37 \mathrm{bc}$ \\
\hline M-Pede ${ }^{\circledR}$ & $8.3 \mathrm{~mL} / \mathrm{L}(0.83 \%)$ & $1.80 \mathrm{bcd}$ & $1.63 \mathrm{bcd}$ & $1.00 \mathrm{hr}$ & $1.80 \mathrm{bc}$ & $2.37 \mathrm{bc}$ \\
\hline Armicarb $^{\circledR}$ & $6.6 \mathrm{~g} / \mathrm{L}(0.05 \mathrm{lb} / \mathrm{gal})$ & $1.30 \mathrm{~cd}$ & $2.00 \mathrm{~b}$ & 2.37 bcde & $1.30 \mathrm{~cd}$ & $2.00 \mathrm{c}$ \\
\hline Bayleton & $0.9 \mathrm{~g} / \mathrm{L}(0.12 \mathrm{oz} / \mathrm{gal})$ & $2.10 \mathrm{bcd}$ & $2.00 \mathrm{~b}$ & $2.75 \mathrm{bc}$ & $2.10 \mathrm{bc}$ & $2.25 \mathrm{bc}$ \\
\hline Triact $70^{\circledR}$ & $10.0 \mathrm{~mL} / \mathrm{L}(1.0 \%)$ & $1.20 \mathrm{~cd}$ & $1.75 \mathrm{bc}$ & $1.37 \mathrm{gh}$ & $1.20 \mathrm{~cd}$ & $2.75 \mathrm{~b}$ \\
\hline Compass $^{\circledR} /$ Sevin $^{\circledR}$ & $0.3 \mathrm{~g} / \mathrm{L}(0.04 \mathrm{oz} / \mathrm{gal})$ & $2.80 \mathrm{a}$ & $1.05 \mathrm{~cd}$ & $2.50 \mathrm{bcd}$ & $2.80 \mathrm{a}$ & $2.12 \mathrm{c}$ \\
\hline Water control & - & $3.30 \mathrm{a}$ & $4.50 \mathrm{a}$ & $3.50 \mathrm{a}$ & $3.10 \mathrm{a}$ & $3.87 \mathrm{a}$ \\
\hline $\begin{array}{l}\operatorname{LSD}_{(0.05)} \\
0.60\end{array}$ & & 0.67 & & 0.66 & 0.57 & 0.67 \\
\hline
\end{tabular}

${ }^{\mathrm{z}}$ Fungicides Bayleton (triadimefon) and Compass ${ }^{\circledR}$ (trifloxystrobin) were applied starting early May and the insecticide Sevin ${ }^{\circledR}$ (carbaryl) was added in a tank mix starting in mid-June when Japanese beetles were detected in insect traps.

${ }^{\mathrm{y}}$ Disease severity readings: $1=1 \%$ to $10 \%, 2=11 \%$ to $25 \%, 3=26 \%$ to $50 \%, 4=51 \%$ to $75 \%$, and $5=76 \%$ to $100 \%$ plant showing symptoms. Numbers followed by common letters in the same column are statistically similar at $P=0.05$ according to analysis of variance (Proc GLM) and least significant differences (LSD) calculated by Statistical Analysis Systems (SAS Institute 1990).

${ }^{\mathrm{x}}$ Shadehouse experiment was repeated in 2004 and similar results were obtained (data not shown).

eventually covered the entire leaf surface. In 2002, disease pressure was moderate with only $50 \%$ of the nontreated foliage showing symptoms in the shadehouse, field, and greenhouse trials. However, in 2003, disease pressure was high in greenhouse trial and moderately high in the field trial as indicated by disease severity in the nontreated plants (Table 1). All biopesticides, including household soaps (Ajax ${ }^{\circledR}$ and Equate ${ }^{\circledR}$ ), bicarbonate salt (Armicarb ${ }^{\circledR}$, Helena Chemicals Company, Collierville, TN), neem seed oil extract (Triact $70^{\circledR}$, ThermoTriology Corp., Columbia, MD and Neem Gold ${ }^{\circledR}$, Biocontrol Network, Brentwood, TN), and kaolin clay (Surround ${ }^{\circledR}$, Engelhard Corp., Iselin, NJ), were effective in reducing powdery mildew disease severity (Table 1).

Initial symptoms of black spot were observed in late May in shadehouse and field trials, but the disease did not develop in the greenhouse. Black spot symptoms in roses were characterized by black necrotic lesions ( 2 to $12 \mathrm{~mm}$ [0.08 in to $0.48 \mathrm{in}]$ in diameter) that were circular or irregular in shape with radiate, feathery margins and a chlorotic halo (Figure 1B). Black spot disease was associated with defoliation and by mid-June, the nontreated plants had greater than $80 \%$ to 90\% defoliation. Disease severity was moderate in 2002 and high in 2003 (Table 2), and the nontreated plants had defoliated approximately 50\% to $75 \%$ in 2002 and greater than $80 \%$ to $90 \%$ in 2003 . Some treatments were slightly more effective than others in reducing black spot disease severity in individual trials. However, there were no statistical differences between biopesticide and conventional fungicide treat-
Table 2. Black spot (Marssonina rosae, anamorph Diplocarpon rosae) disease severity in roses (Rosa spp.) treated with different products under field environments.

\begin{tabular}{|c|c|c|c|}
\hline \multirow[b]{2}{*}{ Treatment $^{\mathrm{z}}$} & \multicolumn{3}{|c|}{ Highest disease severity $(0-5 \text { scale })^{\mathrm{y}}$} \\
\hline & $\begin{array}{l}\text { Application rate } \\
\text { (product/L of water) }\end{array}$ & 2002 & 2003 \\
\hline Equate $^{\circledR}$ & $18.3 \mathrm{~mL} / \mathrm{L}(1.8 \%)$ & $1.50 \mathrm{~cd}$ & $1.00 \mathrm{e}$ \\
\hline UltraFine ${ }^{\circledR}$ & 14.0 mL/L (1.4\%) & $1.80 \mathrm{bc}$ & $1.50 \mathrm{bcde}$ \\
\hline $\operatorname{Ajax}^{\circledR}$ & $18.3 \mathrm{~mL} / \mathrm{L}(1.8 \%)$ & $1.10 \mathrm{~d}$ & $1.13 \mathrm{de}$ \\
\hline Surround ${ }^{\circledR}$ & $30 \mathrm{~g} / \mathrm{L}(0.25$ lb/gal $)$ & $1.50 \mathrm{~cd}$ & $1.75 \mathrm{bcd}$ \\
\hline Neem Gold ${ }^{\circledR}$ & $10.0 \mathrm{~mL} / \mathrm{L}(1.0 \%)$ & $2.20 \mathrm{ab}$ & $1.25 \mathrm{cde}$ \\
\hline M-Pede ${ }^{\circledR}$ & 8.3 mL/L (0.83\%) & $1.80 \mathrm{bc}$ & $1.63 \mathrm{bcde}$ \\
\hline Armicarb $^{\circledR}$ & $6.6 \mathrm{~g} / \mathrm{L}(0.05 \mathrm{lb} / \mathrm{gal})$ & $1.30 \mathrm{~cd}$ & $2.00 \mathrm{~b}$ \\
\hline Bayleton & $0.9 \mathrm{~g} / \mathrm{L}(0.12 \mathrm{oz} / \mathrm{gal})$ & $2.10 \mathrm{bc}$ & $2.00 \mathrm{~b}$ \\
\hline Triact $70^{\circledR}$ & $10.0 \mathrm{~mL} / \mathrm{L}(1.0 \%)$ & $1.20 \mathrm{~cd}$ & $1.75 \mathrm{bcd}$ \\
\hline $\begin{array}{l}\text { Insecticide and } \\
\text { fungicide }\end{array}$ & $0.3 \mathrm{~g} / \mathrm{L}(0.04 \mathrm{oz} / \mathrm{gal})$ & $2.80 \mathrm{a}$ & $1.05 \mathrm{de}$ \\
\hline Control & - & $3.10 \mathrm{a}$ & $4.50 \mathrm{a}$ \\
\hline $\operatorname{LSD}_{(0.05)}$ & & 0.63 & 0.65 \\
\hline
\end{tabular}

${ }^{\mathrm{z}}$ Fungicides Bayleton (triadimefon) and Compass ${ }^{\circledR}$ (trifloxystrobin) were applied starting early May and the insecticide Sevin ${ }^{\circledR}$ (carbaryl) was added in a tank mix starting in mid-June when Japanese beetles were detected in insect traps.

${ }^{\mathrm{y}}$ Disease severity readings: $1=1 \%$ to $10 \%, 2=11 \%$ to $25 \%, 3=26 \%$ to $50 \%, 4=51 \%$ to $75 \%$, and $5=76 \%$ to $100 \%$ plant showing symptoms. Numbers followed by common letters in the same column are statistically similar at $P=0.05$ according to analysis of variance (Proc GLM) and least significant differences (LSD) calculated by Statistical Analysis Systems (SAS Institute 1990). 
Table 3. Bacteria leaf spot (Xanthomonas campestris) disease severity in oakleaf hydrangea (Hydrangea quercifolia) and powdery mildew (Lagerstroemia australiana) in crapemyrtle (Lagestroemia indica) treated with different disease control products in the field environment.

\begin{tabular}{|c|c|c|c|c|c|}
\hline \multirow[b]{3}{*}{ Treatment $^{\mathrm{z}}$} & \multirow{3}{*}{$\begin{array}{l}\text { Application rate } \\
\text { (product/L of water) }\end{array}$} & \multicolumn{4}{|c|}{ Highest disease severity $(0-5 \text { scale })^{\mathrm{y}}$} \\
\hline & & \multicolumn{2}{|c|}{ Bacteria leaf spot in oakleaf hydrangea } & \multicolumn{2}{|c|}{ Powdery mildew in crapemyrtle } \\
\hline & & 2002 & 2003 & 2002 & 2003 \\
\hline Surround ${ }^{\circledR}$ & $30 \mathrm{~g} / \mathrm{L}(0.25 \mathrm{lb} / \mathrm{gal})$ & $0.67 \mathrm{~d}$ & $1.50 \mathrm{c}$ & $0.00 \mathrm{~d}$ & $0.00 \mathrm{~d}$ \\
\hline Neem Gold ${ }^{\circledR}$ & $8.3 \mathrm{~mL} / \mathrm{L}(0.83 \%)$ & $1.17 \mathrm{bcd}$ & $1.67 \mathrm{bc}$ & $1.92 \mathrm{bc}$ & $1.10 \mathrm{bc}$ \\
\hline Triact $70^{\circledR}$ & $8.3 \mathrm{~mL} / \mathrm{L}(0.83 \%)$ & $1.25 \mathrm{bcd}$ & $2.00 \mathrm{abc}$ & $1.83 \mathrm{c}$ & $1.00 \mathrm{bc}$ \\
\hline $\operatorname{Ajax}^{\circledR}$ & $18.3 \mathrm{~mL} / \mathrm{L}(1.8 \%)$ & $1.00 \mathrm{~cd}$ & $2.00 \mathrm{abc}$ & $1.92 \mathrm{bc}$ & $1.10 \mathrm{bc}$ \\
\hline UltraFine $^{\circledR}$ Oil & $14.0 \mathrm{~mL} / \mathrm{L}(1.4 \%)$ & $1.83 \mathrm{ab}$ & $2.33 \mathrm{a}$ & $2.17 \mathrm{bc}$ & $1.50 \mathrm{abc}$ \\
\hline M-Pede ${ }^{\circledR}$ & $8.3 \mathrm{~mL} /(0.83 \%)$ & $1.33 \mathrm{abcd}$ & $1.67 \mathrm{bc}$ & $1.58 \mathrm{bc}$ & $1.20 \mathrm{bc}$ \\
\hline Equate $^{\circledR}$ & $18.3 \mathrm{~mL} / \mathrm{L}(1.8 \%)$ & $1.08 \mathrm{~cd}$ & $2.0 \mathrm{abc}$ & $1.58 \mathrm{bc}$ & $1.20 \mathrm{bc}$ \\
\hline Armicarb $^{\circledR}$ & $6.6 \mathrm{~g} / \mathrm{L}(0.05 \mathrm{lb} / \mathrm{gal})$ & $1.42 \mathrm{abc}$ & $2.0 \mathrm{abc}$ & $2.17 \mathrm{bc}$ & $1.50 \mathrm{abc}$ \\
\hline Bayleton & $0.9 \mathrm{~g} / \mathrm{L}(0.12 \mathrm{oz} / \mathrm{gal})$ & $1.58 \mathrm{ab}$ & $2.17 \mathrm{ab}$ & $2.33 \mathrm{bc}$ & $1.50 \mathrm{abc}$ \\
\hline Sevin $^{\circledR} /$ Compass ${ }^{\circledR}$ & $0.3 \mathrm{~g} / \mathrm{L}(0.04 \mathrm{oz} / \mathrm{gal})$ & $1.33 \mathrm{abcd}$ & $1.83 \mathrm{bc}$ & $1.95 \mathrm{bc}$ & $1.20 \mathrm{bc}$ \\
\hline Control & - & $2.08 \mathrm{a}$ & $2.17 \mathrm{ab}$ & $3.5 \mathrm{a}$ & $2.10 \mathrm{a}$ \\
\hline $\operatorname{LSD}_{(0.05)}$ & & 0.77 & 0.50 & 1.13 & 0.75 \\
\hline
\end{tabular}

${ }^{\mathrm{z}}$ Fungicides Bayleton (triadimefon) and Compass ${ }^{\circledR}$ (trifloxystrobin) were applied starting early May and the insecticide Sevin ${ }^{\circledR}$ (carbaryl) was added in a tank mix starting in mid-June when Japanese beetles were detected in insect traps.

${ }^{\mathrm{y}}$ Disease severity readings: $1=1 \%$ to $10 \%, 2=11 \%$ to $25 \%, 3=26 \%$ to $50 \%, 4=51 \%$ to $75 \%$, and $5=76 \%$ to $100 \%$ plant showing symptoms. Numbers followed by common letters in the same column are statistically similar at $P=0.05$ according to analysis of variance (Proc GLM) and least significant differences (LSD) calculated by Statistical Analysis Systems (SAS Institute 1990).

ments in repeated trials. All biopesticides were consistently better than the nontreated control and as effective as the conventional fungicides (Table 2).

The oakleaf hydrangea plants had appeared healthy when purchased in a dormant state without leaves. However, a bacterial leaf spot (X. campestris) developed in May and gradually increased in severity throughout the season. Infection was characterized by angular purple to reddish brown spots that were often delineated by leaf veins. The symptoms started on the lower leaves and spread toward the upper ones (Figure 1A). Only kaolin (Surround ${ }^{\circledR}$ ) was significantly better than the other treatments in controlling bacterial leaf spot in repeated trials (Table 3). Most of the products caused leaf burn, especially on leaf tips. The highest percentage of burn was observed in the August Ajax ${ }^{\circledR}$ treatment with $17.4 \%$ of the leaves showing phytotoxicity. The overall treatment effects from kaolin clay (Surround ${ }^{\circledR}$ ) and azadirachtin (Neem Gold $^{\circledR}$ ) were better than the nontreated control in repeated years (Table 3 ).

Crapemyrtle developed powdery mildew, but infection was low and persistent during the early season and decreased as temperatures increased. Kaolin (Surround ${ }^{\circledR}$ ) was highly effective in controlling the disease, whereas all other treatments had similar effects and generally better than nontreated control (Table 3). Kaolin was statistically better than the standard commercial fungicides (Bayleton [Bayer Environmental Sciences, Montvale, NJ] and Compass).

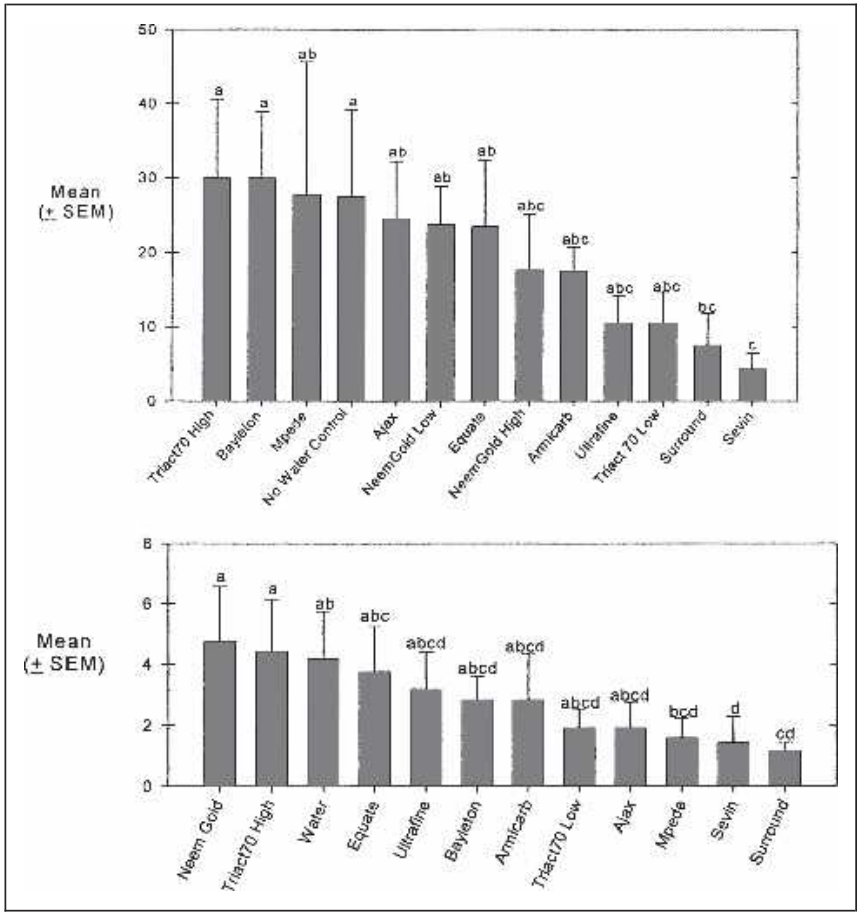

Figure 2. Mean feeding damage and standard error (mean \pm standard error of mean) from adult Japanese beetle in (A) rose (Rosa spp.) planted in the shadehouse and (B) oakleaf hydrangea (Hydrangea quercifolia Bartr.) planted in the field during 2002. 
Table 4. Mean percentage of total leaf area damaged by Japanese beetle (Popillia japonica) in roses (Rosa spp.) treated with different biopesticides during 2003 field and shadehouse trials.

\begin{tabular}{|c|c|c|c|c|c|}
\hline \multirow[b]{3}{*}{ Treatment $^{\mathrm{z}}$} & \multirow{3}{*}{$\begin{array}{l}\text { Application rate } \\
\text { (product/L of water) }\end{array}$} & \multicolumn{4}{|c|}{ Mean $\%$ leaf damage ${ }^{y}$} \\
\hline & & \multicolumn{2}{|c|}{ Field } & \multicolumn{2}{|c|}{ Shadehouse } \\
\hline & & 28 July & 8 August & 29 July & 8 August \\
\hline Sevin ${ }^{\circledR}$ & $0.3 \mathrm{~g} / \mathrm{L}(0.04 \mathrm{oz} / \mathrm{gal})$ & $1.25 \mathrm{c}$ & $0.70 \mathrm{c}$ & $6.63 \mathrm{~cd}$ & $4.50 \mathrm{c}$ \\
\hline Surround ${ }^{\circledR}$ & $30 \mathrm{~g} / \mathrm{L}(0.25 \mathrm{lb} / \mathrm{gal})$ & $0.83 \mathrm{c}$ & $1.13 \mathrm{bc}$ & $7.63 \mathrm{~cd}$ & $7.50 \mathrm{c}$ \\
\hline UltraFine $^{\circledR}$ Oil & $14.0 \mathrm{~mL} / \mathrm{L}(1.4 \% \mathrm{v} / \mathrm{v})$ & $1.50 \mathrm{bc}$ & $1.42 \mathrm{bc}$ & $10.13 \mathrm{bcd}$ & $10.50 \mathrm{abc}$ \\
\hline Triact $70^{\circledR}$ & $8.3 \mathrm{~mL} / \mathrm{L}(0.83 \% \mathrm{v} / \mathrm{v})$ & $5.83 \mathrm{ab}$ & $2.60 \mathrm{bc}$ & $12.63 \mathrm{abcd}$ & $10.50 \mathrm{abc}$ \\
\hline $\operatorname{Ajax}^{\circledR}$ & $18.3 \mathrm{~mL} / \mathrm{L}(1.8 \% \mathrm{v} / \mathrm{v})$ & $3.67 \mathrm{abc}$ & $5.60 \mathrm{ab}$ & $23.75 \mathrm{abcd}$ & $24.50 \mathrm{abc}$ \\
\hline Armicarb $^{\circledR}$ & $6.6 \mathrm{~g} / \mathrm{L}(0.05 \mathrm{lb} / \mathrm{gal})$ & $2.67 \mathrm{bc}$ & $4.40 \mathrm{abc}$ & $20.00 \mathrm{abcd}$ & $17.50 \mathrm{abc}$ \\
\hline Neem Gold ${ }^{\circledR}$ & $8.3 \mathrm{~mL} / \mathrm{L}(0.83 \% \mathrm{v} / \mathrm{v})$ & $3.25 \mathrm{abc}$ & $3.60 \mathrm{bc}$ & $30.00 \mathrm{abc}$ & $23.75 \mathrm{abc}$ \\
\hline Equate $^{\circledR}$ & $18.3 \mathrm{~mL} / \mathrm{L}(1.8 \% \mathrm{v} / \mathrm{v})$ & $1.60 \mathrm{bc}$ & $2.90 \mathrm{bc}$ & $32.50 \mathrm{ab}$ & $23.50 \mathrm{abc}$ \\
\hline M-Pede ${ }^{\circledR}$ & $8.3 \mathrm{~mL} / \mathrm{L}(0.83 \% \mathrm{v} / \mathrm{v})$ & $2.00 \mathrm{bc}$ & $4.40 \mathrm{abc}$ & $35.00 \mathrm{a}$ & $27.75 \mathrm{ab}$ \\
\hline Bayleton & $0.9 \mathrm{~g} / \mathrm{L}(0.12 \mathrm{oz} / \mathrm{gal})$ & $5.33 \mathrm{abc}$ & $5.33 \mathrm{abc}$ & $20.25 \mathrm{abcd}$ & $30.00 \mathrm{a}$ \\
\hline Control & - & $5.17 \mathrm{abc}$ & $9.00 \mathrm{a}$ & 17.00 abcd & $27.50 \mathrm{ab}$ \\
\hline $\operatorname{LSD}_{(0.05)}$ & & 5.38 & 4.67 & 22.64 & 20.25 \\
\hline
\end{tabular}

${ }^{\mathrm{Z}}$ Insecticide Sevin ${ }^{\circledR}$ (carbaryl) was added in a tank mix fungicides Compass ${ }^{\circledR}$ (trifloxystrobin) starting in mid-June when Japanese beetles were detected in insect traps. All other treatments were initiated early May for disease control.

${ }^{\mathrm{y}}$ Mean values followed by common letter within a column are not significantly different according to analysis of variance (Proc GLM) least significant differences on square root transformed data $(X+0.5)$. Dates in which statistical differences were not detected are not shown.

$\mathrm{LSD}=$ least significant difference.

\section{Insect Damage Evaluation}

Adult Japanese beetle feeding damage was observed on leaves and petals of roses. Leaves were often reduced to a net of leaf veins, and petals were often damaged before the flower buds opened (Figures 1C-D). Large numbers of adults tended to aggregate in one place consuming the same plant/ leaves until the food source was exhausted; this may have caused the overall high variation in feeding damage observed among treatments. Feeding damage was highest in July through August. In 2002, kaolin clay (Surround ${ }^{\circledR}$ ) and the conventional insecticide Sevin ${ }^{\circledR}$ were equally effective in controlling feeding damage, with no statistical differences (Figure 2A). In 2003, Sevin ${ }^{\circledR}$ and Surround ${ }^{\circledR}$ were equally and consistently effective in reducing leaf feeding damage on roses in shadehouse and field trials (Table 4). Roses planted in the shadehouse exhibited a higher percentage of feeding damage than those planted in the field, perhaps as a result of the lack of food choice in the shadehouse (Table 4). The overall high variation in feeding damage observed within each treatment may have reduced the level of statistical significance of the data.

Japanese beetle feeding damage on oakleaf hydrangea leaves was highest between mid-July through mid-August (Table 5). Surround ${ }^{\circledR}$ was equally effective as conventional insecticide Sevin ${ }^{\circledR}$ in controlling Japanese beetle feeding damage on oakleaf hydrangea (Figure 2B). Similar results were observed on crapemyrtle (Figure 3). Variation of treatment effects by date was typical for all crapemyrtle trials.
Table 5. Mean percentage of total leaf area damaged by Japanese beetle (Popillia japonica) adults on oakleaf hydrangea (Hydrangea quercifolia) plants treated with different biopesticides during 2003 field trial.

\begin{tabular}{lcll}
\hline & $\begin{array}{c}\text { Application rate } \\
\text { (product/L of water) }\end{array}$ & \multicolumn{2}{c}{ Mean $\%$ leaf damage } \\
\cline { 3 - 4 } Treatment $^{\mathrm{z}}$ & $31 \mathrm{July}$ & 14 August \\
\hline Surround $^{\circledR}$ & $30 \mathrm{~g} / \mathrm{L}(0.25 \mathrm{lb} / \mathrm{gal}$ & $1.40 \mathrm{~cd}$ & $0.92 \mathrm{~cd}$ \\
Sevin $^{\circledR}$ & $0.3 \mathrm{~g} / \mathrm{L}(0.04 \mathrm{oz} / \mathrm{gal})$ & $1.25 \mathrm{c}$ & 0.67 \\
Neem Gold $^{\circledR}$ & $8.3 \mathrm{~mL} / \mathrm{L}(0.83 \%)$ & $2.40 \mathrm{bc}$ & $1.40 \mathrm{~cd}$ \\
Bayleton & $0.9 \mathrm{~g} / \mathrm{L}(0.12 \mathrm{oz} / \mathrm{gal})$ & $2.40 \mathrm{bc}$ & $4.17 \mathrm{abc}$ \\
UltraFine $^{\circledR}$ Oil & $14.0 \mathrm{~mL} / \mathrm{L}(1.4 \%)$ & $2.58 \mathrm{bc}$ & $3.58 \mathrm{abc}$ \\
Kaligreen & $6.6 \mathrm{~g} / \mathrm{L}(0.05 \mathrm{lb} / \mathrm{gal})$ & $2.67 \mathrm{bc}$ & $3.58 \mathrm{abc}$ \\
M-Pede $^{\circledR}$ & $8.3 \mathrm{~mL} / \mathrm{L}(0.83 \%)$ & $3.58 \mathrm{bc}$ & $3.33 \mathrm{bcd}$ \\
Equate $^{\circledR}$ & $18.3 \mathrm{~mL} / \mathrm{L}(1.8 \%)$ & $3.67 \mathrm{~b}$ & $3.33 \mathrm{abc}$ \\
Triact $70^{\circledR}$ & $8.3 \mathrm{~mL} / \mathrm{L}(0.83 \%)$ & $4.75 \mathrm{~b}$ & $3.33 \mathrm{abc}$ \\
Ajax $^{\circledR}$ & $18.3 \mathrm{~mL} / \mathrm{L}(1.8 \%)$ & $3.33 \mathrm{bc}$ & $8.42 \mathrm{a}$ \\
Armicarb $^{\circledR}$ & $6.6 \mathrm{~g} / \mathrm{L}(0.05 \mathrm{lb} / \mathrm{gal})$ & $7.67 \mathrm{a}$ & $5.92 \mathrm{ab}$ \\
Control $^{\circledR}$ & - & $5.50 \mathrm{ab}$ & $5.17 \mathrm{ab}$ \\
LSD $_{(0.05)}$ & & 2.87 & 2.41 \\
\hline
\end{tabular}

${ }^{\mathrm{Z}}$ Insecticide Sevin ${ }^{\circledR}$ (carbaryl) was added in a tank mix with fungicide Compass $^{\circledR}$ (trifloxystrobin) starting in mid-June when Japanese beetles were detected in insect traps. All other treatments were initiated in early May for disease control.

${ }^{y}$ Mean values followed by common letter within a column are not significantly different according to analysis of variance (Proc GLM) least significant differences on square root transformed data $(\sqrt{X}+0.5)$ (SAS Institute 1990). Dates in which statistical differences were not detected are not shown. LSD $=$ least significant difference. 


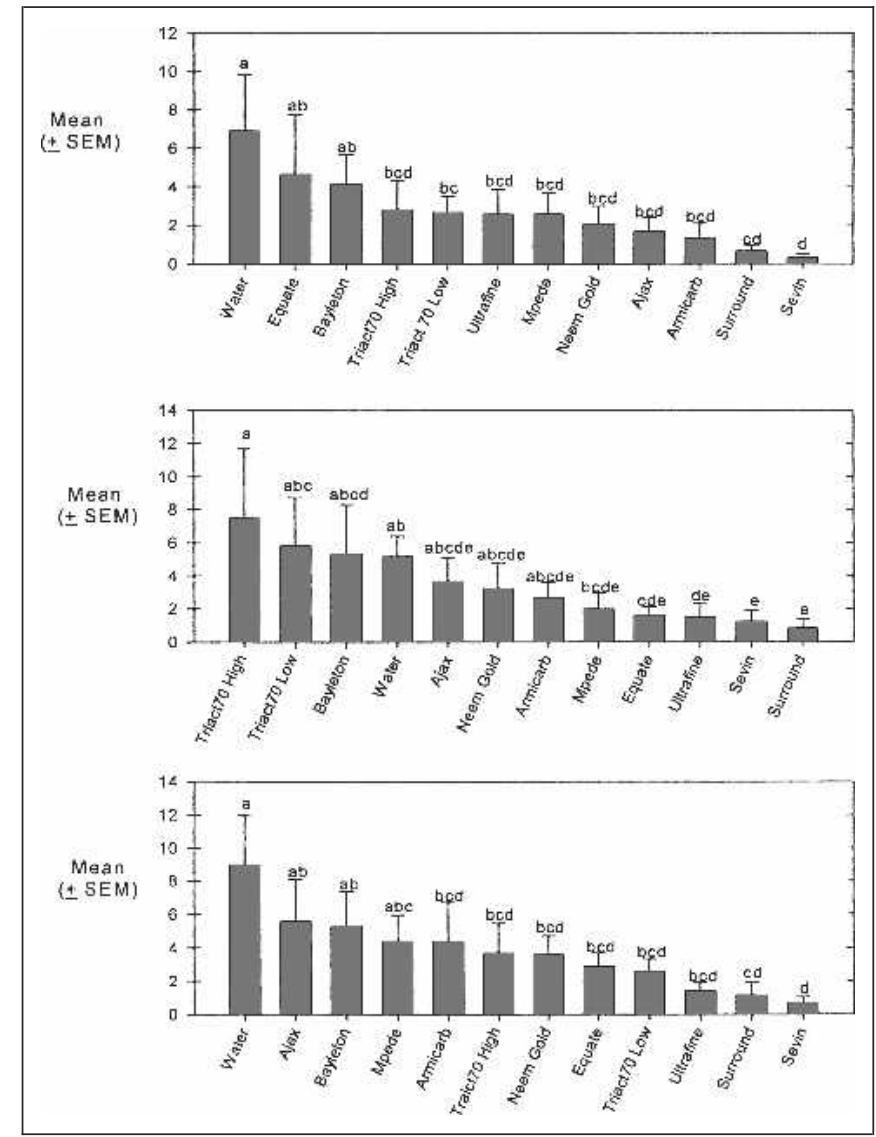

Figure 3. Mean feeding damage and standard error (mean \pm standard error of mean) from adult Japanese beetle in field trials for crapemyrtle (Lagerstroemia indica L.) during 2002 on (A) 11 July, (B) 28 July, and (C) 8 August.

Despite these variations, Surround ${ }^{\circledR}$ was consistently similar to Sevin ${ }^{\circledR}$ in controlling feeding damage from adult Japanese beetles (Figure 3).

\section{DISCUSSION}

Alternative products for pest management, which are environmentally friendly and safer for workers, would be a valuable addition to nursery production systems and landscape industry. In this study, we evaluated a number of biopesticides that are U.S. Environmental Protection Agencyregistered as pesticides and other nonregistered products that are commercially available and have previously shown potential to control foliar diseases and pests. Among the products evaluated, the neem-based product (Triact $70^{\circledR}$ ) was effective in reducing foliar diseases on roses in agreement with reports by Horst et al. (1992) and Locke (1992, 1993). Other neem-based material (Neem Gold ${ }^{\circledR}$ ) was not as effective (Tables 1 and 2). Weekly applications of conventional fungicides such as strobilurines, triazoles, and benzimidazoles are typically used to manage powdery mildew, whereas bimonthly applications are used on black spot (Horst 1995). In our study, all products evaluated, including household soaps $\left(\right.$ Ajax $^{\circledR}$ and Equate ${ }^{\circledR}$ ), bicarbonate salt (Armicarb ${ }^{\circledR}$ ), neem seed oil extract (Triact $70^{\circledR}$ and Neem Gold ${ }^{\circledR}$ ), and kaolin clay (Surround ${ }^{\circledR}$ ) were more effective than the nontreated control and as effective as the conventional fungicides in reducing powdery mildew and black spot in roses (Tables 1 and 2). Only Surround ${ }^{\circledR}$ was consistently effective in controlling bacterial leaf spot on oakleaf hydrangea, and it was the best product for controlling powdery mildew in crapemyrtle (Table 3). Surround ${ }^{\circledR}$, UltraFine ${ }^{\circledR}$ Sunspray oil (Whitmire Micro-Gen Research Laboratories, Inc., St. Louis, MO), Armicarb $^{\circledR}$, and M-Pede ${ }^{\circledR}$ (Mycogen Corp., San Diego, CA) are registered biopesticides for ornamental plants. Household soaps are not registered for use as biopesticides, but they are considered safe enough for household use and have repeatedly shown potential for controlling foliar diseases (Mmbaga and Sauvé 2004; Sholberg and Boulé 2006). The slight leaf burn problem associated with soap use on hot sunny days may be eliminated by concentration adjustments. Recently, a lower soap concentration at $0.5 \%$ to $1.0 \%$ was shown to be as effective as a conventional fungicide program in controlling powdery mildew fungi in apple, cherry, and grape (Sholberg and Boulé 2006). These results support previous reports that biopesticides may be incorporated in disease management and reduce the dependence on conventional fungicides (Mmbaga and Sauvé 2004).

Household soaps were not effective in reducing Japanese beetle feeding damage. Although the insecticidal soap MPede ${ }^{\circledR}$ showed some potential in reducing adult Japanese beetle feeding damage in oakleaf hydrangea and crapemyrtle, its effect was not consistent (Figures 2 and 3). M-Pede ${ }^{\circledR}$ has been reported to be toxic to beetles like coccinellid lady birds (Smith and Krischik 2000) and may have some toxicity to Japanese beetle. Neem-based products have been reported to have insect-repelling properties (Ladd et al. 1978; Held et al. 2001; Showler et al. 2004). However, Triact ${ }^{\circledR}$ and Neem Gold ${ }^{\circledR}$ were inconsistent and not effective in our studies. Surround ${ }^{\circledR}$ was the only product that showed potential in controlling Japanese beetle feeding damage, and it was as effective as the conventional insecticide Sevin ${ }^{\circledR}$. Overall, Surround ${ }^{\circledR}$ was the most effective compound for both pathogen and insect control.

A disadvantage in using Surround ${ }^{\circledR}$ is the white residue film that forms on plant foliage, which reduces the aesthetic appearance of landscape plants. The white film was temporary and eventually washed off with overhead irrigation or rainfall. The sale of field nursery plants is mostly in spring when plants are dormant and have no leaves; therefore, no white Surround ${ }^{\circledR}$ film would interfere with plant aesthetics. Thus, Surround ${ }^{\circledR}$ would be a good alternative product in controlling adult Japanese beetle feeding in nurseries. In addition 
to being effective, Surround ${ }^{\circledR}$ has no restricted entry time, which is a major advantage in nursery production systems where reentry restrictions to sprayed areas can interfere with production activities. The availability of products that allow safe reentry to treated areas reduces the hazard of accidental human pesticide exposure. These products would also be useful additions in landscape settings.

Acknowledgments. We thank Qian Zhang, Mario Keri, Nadeer Youssef, Hongyan Sheng, Andrew Trivette, Debbie Eskandarnia, Laura Oma, Crystal Lemings, Joshua Basham, and Caleb West for their assistance during these studies. This project was funded by U.S. Environmental Protection Agency Strategic Agricultural Initiative Project No. 97437601

\section{LITERATURE CITED}

Bélanger, R.R., and C. Labbé. 2002. Control of powdery mildew without chemicals: Prophylactic and biological alternatives for horticultural crops, pp. 256-267. In The Powdery Mildews: Comprehensive Treatise. Bélanger, R.R., Bushnell, W.R., Dik, A.J., and Carver, T.L.W., Eds. APS Press, St. Paul, MN.

Bradley, J.R. Jr. 1999. Integrating new insecticide technologies in IPM, pp. 384-399. In Proc. Emerging Technologies for Integrated Pest Management. Concepts, Research, and Implementation, 8-10 March 1999. Kennedy, G.G., and Sutton, T.B., Eds. APS Press, Raleigh, NC.

Clement, D.L., S.A. Gill, and W. Potts. 1994. Alternative to powdery mildew control in lilac. Journal of Arboriculture 20:227-230.

Daughtrey, M.L., and A.K. Hagan. 2001. Dogwood diseases, pp. 124-132. In Diseases of Woody Ornamentals and Trees in Nurseries. Jones, R.K., and Benson, M.D., Eds. APS Press, St. Paul, MN.

Ellis, M.A., D.C. Ferree, and D.E. Spring. 1981. Photosynthesis, transpiration, and carbohydrate content of apple leaves infected by Podosphaera leucotricha. Phytopathology 71:392-395.

Garber, M.P., and W.G. Hudson. 1996. Pest management in the United States greenhouse and nursery industry: Introduction and perspective. HortTechnology 6:194-221.

Gomez, K.A., and A.A. Gomez. 1984. Statistical Procedures for Agricultural Research. John Wiley and Sons, New York, NY. 679 pp.

Hagan, A., and J. Mullen. 1995. Controlling powdery mildew on ornamentals. Alabama Coop. Ext. Sys. Cir. ANR-407.

Held, D.W., T. Eaton, and D.A. Potter. 2001. Potential for habituation to a neem-based feeding deterrent in Japanese beetles, Popillia japonica. Entomol. Exper. Applic. 101: 25-32.

Horsfall, J.G., and R.W. Barratt. 1945. An improved grading system for measuring plant disease (Abstr.). Phytopathology 35:655.

Horst, R.K., S.O. Kawamoto, and L.L. Porter. 1992. Effect of sodium bicarbonate and oils on the control of powdery mildew and black spot of roses. Plant Disease 76: 247-251.

Horst, R.K. 1995. Compendium of Rose Diseases. APS Press, St. Paul, MN. 50 pp.

Isman, M.B. 1994. Botanical insecticides. Pesticide Outlook 5:6-30.

Jones, R.K., and D.M. Benson. 2004. Diseases of woody ornamentals and tree nurseries. APS Press, St. Paul, MN. $482 \mathrm{pp}$.

Ladd, T.L. Jr., M. Jacobson, and C.R. Buriff. 1978. Japanese beetles: Extracts from neem tree seeds as feeding deterrents. Journal of Economic Entomology 71:810-813.

Landolt, P.J., R.W. Hofstetter, and L.L. Biddick. 1999. Plant essential oils as arrestants and repellents for neonate larvae of the codling moth (Lepidoptera: Tortricidae). Environmental Entomology 28:954-960.

Locke, J.C. 1992. Comparison of neem oil Sunspray 6E Plus, horticultural oil and benlate for control of powdery mildew on greenhouse hydrangea. Phytopathology 82:1121.

- 1993. Field evaluation of clarified neem seed oil, Sunspray 6E Plus Horticultural oil and Funginex for control of powdery mildew on perennial garden phlox. Pytopathology. 83:1337.

Mmbaga, M.T., and H. Sheng. 2002. Evaluation of biorational products for powdery mildew management in Cornus florida. Journal of Environmental Horticulture 20: 113-117.

Mmbaga, M.T., and R.J. Sauvé. 2004. Management of powdery mildew in flowering dogwood with biorational products and fungicides. Canadian Journal of Plant Science 84:837-844.

Philley, G., A.K. Hagan, and A.R. Chase. 2001. Rose diseases, pp. 342-348. In Diseases of Woody Ornamentals and Trees in Nurseries. Jones, R.K., and Benson, M.D., Eds. APS Press, St. Paul, MN. 481 pp.

SAS Institute. 1990. SAS/STAT Users Guide, Version 6. Statistical Analysis Systems Institute, Inc., Cary, NC. 890 pp.

Schlotzauer, S.D., and R.C. Littell. 1987. SAS system for elementary statistical analysis. SAS Institute, Inc., Cary, NC. 416 pp.

Scott, I.M., H. Jensen, R. Nicol, L. Lesage, R. Bradbury, P. Sanchez-Vindas, L. Poveda, J.T. Arnason, and B.J.R. Philogene. 2004. Efficacy of Piper (Piperaceae) extracts for control of common home and garden insects pests. Journal of Economic Entomology 97:1390-1403.

Shi, A., and M.T. Mmbaga. 2006. Perpetuation of powdery 
mildew infection and identification of Erysiphe australiana as the crape myrtle pathogen in mid-Tennessee. Plant Disease 90:1098-1101.

Sholberg, P.L., and J. Boulé. 2006. Control of apple, cherry and grape powdery mildew with commercial sap solutions. American Phytopathological Society, Canadian Phytopathological Society and Mycological Society of America meeting presentation abstracts, p. 180.

Showler, A.T., S.M. Greenberg, and J.T. Arnason. 2004. Deterrent effects of four neem-based formulations on gravid boll weevil (Coleoptera: Curculionidae) feeding and oviposition on cotton squares. Journal of Economic Entomology 97:414-421.

Sinclair, W.A., H. Lyon, and W.T. Johnson. 1993. Diseases of trees and shrubs. Cornell Univ. Press. Ithaca, NY. 575 pp.

Smith, S.F., and V.A. Krischik. 2000. Effects of biorational pesticides on four coccinellid species (Coleoptera: Coccinellidae) having potential as biological control agents in interiorscapes. Journal of Economic Entomology 93: 732-736.

Stimmel, J.F. 1996. Biorational controls-Problem-free? Regulatory Horticulture. 22:1-3.

TOR. 2005. Greenbook Turf \& Ornamental Reference for Plant Protection Products. Vance Communication Corp., New York, NY.

U.S. EPA. 2005a. http://www.epa.gov/pesticides/biopesticides/ whatarebiopesticides.htm (assessed 04/06).

_ 2005b. http://www.epa.gov/oppbppd1/biopesticides/ ingredients/factsheets/factsheet_plant-oils.htm (assessed 04/06).

Windham, A.S. 1994. Disease management of woody ornamentals in nurseries and commercial landscapes. Univ. Tennessee Agric. Ext. Serv. PB 1234-25M.

\section{M.T. Mmbaga (corresponding author)}

Otis L. Floyd Nursery Research Center

Tennessee State University

472 Cadillac Lane

McMinnville, TN 37110, U.S.

mmmbaga@tnstate.edu

\section{J.B. Oliver}

Otis L. Floyd Nursery Research Center

Tennessee State University

472 Cadillac Lane

McMinnville, TN 37110, U.S.

Résumé. Cette étude évalue l'efficacité de biopesticides pour diminuer les maladies foliaires et les dommages causés par l'alimentation des scolytes japonais adultes sur les rosiers hybrides de thé (Rosa spp.), l'Hydrangea quercifolia et le Lagerstroemia indica. Les produits testés incluaient des savons maisons avec du Triclosan comme ingrédient actif (Equate ${ }^{\circledR}$ et Ajax ${ }^{\circledR}$ ), de l'argile de kaolin (Surround ${ }^{\circledR}$ ), de l'extrait de l'huile de neem (Triact $^{\circledR} 70$ et Neem Gold $^{\circledR}$ ), des acides gras de sels de potassium (M-Pede ${ }^{\circledR}$ ), de l'huile horticole (huile estivale UltraFine ${ }^{\circledR}$ ) et du sel de bicarbonate (Armicarb ${ }^{\circledR}$ ) appliqués sur des plants poussant en serre, en tunnel et en milieu extérieur. Deux fongicides, le trifloxystrobin (Strobilurin) et le triadimefon (Triazole) et l'insecticide carbaryl ont été inclus à titre comparatif. Tous les produits testés ont été effectifs pour contrôler la tache noire du rosier (Marssonina rosae, forme anamorphique Diplocarpon rosae) et le blanc des feuilles (Sphaerotheca pannosa) sur les rosiers. La kaoline a été effective pour diminuer la sévérité de la tache bactérienne des feuilles (Xanthomonas campestris) chez l'H. quercifolia ainsi que le blanc des feuilles chez le $L$. indica. En se basant sur les données provenant de tests répétitifs, les biopecticides étaient aussi efficaces que les fongicides conventionnels pour supprimer les maladies foliaires. L'argile de kaoline était aussi efficace que le carbaryl pour contrôler les dommages causés par l'alimentation des adultes du scolyte japonais sur les rosiers, les $H$. quercifolia et les $L$. indica, mais les autres produits ne l'étaient pas. Les résultats de cette étude indiquent que l'argile de kaoline peut être utilisée comme produit alternatif aux pesticides conventionnels pour la gestion des insectes et des maladies chez les rosiers, les $H$. quercifolia et les $L$. indica.

Zusammenfassung. Diese Studie bewertet die Effektivität von Biopestiziden bei der Reduzierung von Blattkrankheiten d Fraßschäden durch Japan-Käfer an Hybridrosen (Rosa spp), Hydrangea quercifolia und Lagerstroemia indica. Das getestete Material enthielt auch Haushaltsseifen mit den aktiven Wirkstoffen Triclosan, Kaolin-Ton, Neembaumsamenölextrakt, Kaliumsalz von Fettsäuren, Pflanzen-Öl und Bicarbonatsalz, die unter Gewächshaus- Folienhaus - und Feldbedingungen getestet wurden. Zwei Fungizide, Strobilurin und Triazole, und das Insektizid Carbaryl wurden zum Vergleich herangezogen. Alle getesteten Materialien waren effektiv bei der Kontrolle von Marssonina rosae, Diclocarpon rosae und Mehltau (Sphaerotheca pannosa) bei Rosen. Kaolin war effektiv bei der Reduzierung der Befallsstärke durch Xanthomonas campestris bei Hydrangea und Mehltau bei Lagerstroemia. Basierend auf den von den wiederholten Versuchen, könne wir sagen, dass die Biopestizide genauso effektiv wie die konventionellen Insektizide waren bei der Krankheitsbekämpfung. Carbaryl war so effektiv wie Kaolin bei der Bekämpfung von dem Japan-Käfer und seine Fraßschäden auf $H y$ drangea, Rosen und Lagerstroemia, aber andere Produkte wirkten nicht. Die Ergebnisse dieser Studie zeigten, dass Kaolin-Ton eine Alternative zu konventionellen Pestiziden bei den genannten Pflanzen sein kann.

Resumen. Este estudio evaluó la eficacia de los biopesticidas para reducir las enfermedades foliares y el daño por alimentación de los escarabajos Japoneses adultos en el híbrido rosa (Rosa spp.), encino (Hydrangea quercifolia) y astronómica (Lagerstroemia indica). Los materiales probados incluyeron jabones caseros con Triclosan como ingrediente activo (Equate ${ }^{\circledR}$ y Ajax ${ }^{\circledR}$ ), arcilla kaolin (Surround ${ }^{\circledR}$ ), extracto de aceite de semilla de nim $\left(\right.$ Triact $^{\circledR} 70$ y Neem Gold ${ }^{\circledR}$ ), sales de potasio de ácidos grasos (M-Pede ${ }^{\circledR}$ ), aceite hortícola (aceite UltraFine ${ }^{\circledR}$ Sunspray), y sal de bicarbonato (Armicarb ${ }^{\circledR}$ ) aplicados a 
plantas en invernadero, a la sombra y en condiciones de campo. Dos fungicidas: trifloxystrobin (Strobilurin) y triadimefon (Triazole) y el insecticida carbaryl fueron incluidos para comparación. Todos los materiales probados fueron efectivos en controlar la mancha bacterial de la hoja (Marssonina rosae, anamorph Diplocarpon rosae) y cenicilla (Sphaerotheca pannosa) de las rosas. El kaolin fue efectivo en reducir la severidad de la enfermedad bacterial de la mancha foliar (Xanthomonas campestris) en encino y cenicilla en manzano.
Con base en datos de ensayos repetidos, los biopesticidas fueron tan efectivos como los fungicidas convencionales en la supresión de las enfermedades foliares. La arcilla kaolin fue tan efectiva como el carbaryl en el control del escarabajo japonés adulto en encino, rosas y manzanos, pero otros productos no fueron tan efectivos. Los resultados de este estudio indican que la arcilla kaolin puede ser una alternativa a los pesticidas convencionales en enfermedades foliares y manejo de plagas de insectos para rosas, encino y manzanos. 